\title{
Kinetic data for MISTRA
}

supplemental material to:

S. Pechtl, E. R. Lovejoy, J. B. Burkholder, and R. von Glasow

Modeling the possible role of iodine oxides in atmospheric new particle formation

Atmos. Chem. Phys. Discuss., 2005

September 6, 2005 


\section{Tables of reaction rates}

This collection comprises a complete listing of all gas and aqueous phase species (Table 1), gas phase (Table 2) and aqueous phase (Table 3) reaction rates, as well as rates for the heterogeneous (particle surface) reactions (Table 4), aqueous phase equilibrium constants (Table 5), Henry constants and accommodations coefficients (Table 7 ).

Table 1: Species

\begin{tabular}{|c|}
\hline Gas phase \\
\hline $\mathrm{O}^{1} \mathrm{D}, \mathrm{O}_{2}, \mathrm{O}_{3}, \mathrm{OH}, \mathrm{HO}_{2}, \mathrm{H}_{2} \mathrm{O}_{2}, \mathrm{H}_{2} \mathrm{O}$ \\
\hline $\mathrm{NO}, \mathrm{NO}_{2}, \mathrm{NO}_{3}, \mathrm{~N}_{2} \mathrm{O}_{5}, \mathrm{HONO}, \mathrm{HNO}_{3}, \mathrm{HNO}_{4}, \mathrm{PAN}, \mathrm{NH}_{3}$ \\
\hline $\begin{array}{l}\mathrm{CO}, \mathrm{CO}_{2}, \mathrm{CH}_{4}, \mathrm{C}_{2} \mathrm{H}_{6}, \mathrm{C}_{2} \mathrm{H}_{4}, \mathrm{HCHO}, \mathrm{HCOOH}, \mathrm{ALD}, \mathrm{CH}_{2} \mathrm{O}_{2}, \mathrm{HOCH}_{2} \mathrm{O}_{2}, \\
\mathrm{CH}_{3} \mathrm{CO}_{3}, \mathrm{CH}_{3} \mathrm{O}_{2}, \mathrm{C}_{2} \mathrm{H}_{5} \mathrm{O}_{2}, \mathrm{EO}_{2}, \mathrm{CH}_{2} \mathrm{O}_{2}, \mathrm{ROOH}\end{array}$ \\
\hline $\begin{array}{l}\mathrm{SO}_{2}, \mathrm{SO}_{3}, \mathrm{HOSO}_{2}, \mathrm{H}_{2} \mathrm{SO}_{4}, \mathrm{DMS}, \mathrm{CH}_{3} \mathrm{SCH}_{2} \mathrm{OO}, \mathrm{DMSO}, \mathrm{DMSO}_{2}, \mathrm{CH}_{3} \mathrm{~S}, \\
\mathrm{CH}_{3} \mathrm{SO}, \mathrm{CH}_{3} \mathrm{SO}_{2}, \mathrm{CH}_{3} \mathrm{SO}_{3}, \mathrm{CH}_{3} \mathrm{SO}_{2} \mathrm{H}, \mathrm{CH}_{3} \mathrm{SO}_{3} \mathrm{H}\end{array}$ \\
\hline $\mathrm{Cl}, \mathrm{ClO}, \mathrm{OClO}, \mathrm{HCl}, \mathrm{HOCl}, \mathrm{Cl}_{2}, \mathrm{Cl}_{2} \mathrm{O}_{2} \mathrm{ClNO}_{2}, \mathrm{ClNO}_{3}$ \\
\hline $\mathrm{Br}, \mathrm{BrO}, \mathrm{HBr}, \mathrm{HOBr}, \mathrm{Br}_{2}, \mathrm{BrNO}_{2}, \mathrm{BrNO}_{3}, \mathrm{BrCl}$ \\
\hline $\begin{array}{l}\text { I, IO, OIO, HI, HOI, INO } \mathrm{INO}_{3}, \mathrm{I}_{2}, \mathrm{ICl}, \mathrm{IBr}, \mathrm{HIO}_{3}, \mathrm{CH}_{3} \mathrm{I}, \mathrm{C}_{2} \mathrm{H}_{5} \mathrm{I}, \mathrm{C}_{3} \mathrm{H}_{7} \mathrm{I}, \\
\mathrm{CH}_{2} \mathrm{ClI}, \mathrm{CH}_{2} \mathrm{BrI}, \mathrm{CH}_{2} \mathrm{I}_{2}\end{array}$ \\
\hline Liquid phase (neutral) \\
\hline $\mathrm{O}_{2}, \mathrm{O}_{3}, \mathrm{OH}, \mathrm{HO}_{2}, \mathrm{H}_{2} \mathrm{O}_{2}, \mathrm{H}_{2} \mathrm{O}$ \\
\hline $\mathrm{NO}, \mathrm{NO}_{2}, \mathrm{NO}_{3}, \mathrm{HONO}, \mathrm{HNO}_{3}, \mathrm{HNO}_{4}, \mathrm{NH}_{3}$ \\
\hline $\mathrm{CO}_{2}, \mathrm{HCHO}, \mathrm{HCOOH}, \mathrm{CH}_{3} \mathrm{OH}, \mathrm{CH}_{3} \mathrm{OO}, \mathrm{CH}_{3} \mathrm{OOH}$ \\
\hline $\mathrm{SO}_{2}, \mathrm{H}_{2} \mathrm{SO}_{4}, \mathrm{DMSO}, \mathrm{DMSO}_{2}, \mathrm{CH}_{3} \mathrm{SO}_{2} \mathrm{H}, \mathrm{CH}_{3} \mathrm{SO}_{3} \mathrm{H}$ \\
\hline $\mathrm{Cl}, \mathrm{HCl}, \mathrm{HOCl}, \mathrm{Cl}_{2}$ \\
\hline $\mathrm{Br}, \mathrm{HBr}, \mathrm{HOBr}, \mathrm{Br}_{2}, \mathrm{BrCl}$ \\
\hline $\mathrm{IO}, \mathrm{HI}, \mathrm{HOI}, \mathrm{I}_{2}, \mathrm{ICl}, \mathrm{IBr}$ \\
\hline Liquid phase (ions) \\
\hline $\mathrm{H}^{+}, \mathrm{OH}^{-}, \mathrm{O}_{2}^{-}$ \\
\hline $\mathrm{NO}_{2}^{-}, \mathrm{NO}_{3}^{-}, \mathrm{NO}_{4}^{-}, \mathrm{NH}_{4}^{+}$ \\
\hline $\mathrm{HCO}_{3}^{-}, \mathrm{CO}_{3}^{-}, \mathrm{HCOO}^{-}$ \\
\hline $\begin{array}{l}\mathrm{HSO}_{3}^{-}, \mathrm{SO}_{3}^{2}-, \mathrm{HSO}_{4}^{-}, \mathrm{SO}_{4}^{2-}, \mathrm{HSO}_{5}^{-}, \mathrm{SO}_{3}^{-}, \mathrm{SO}_{4}^{-}, \mathrm{SO}_{5}^{-}, \mathrm{CH}_{3} \mathrm{SO}_{3}^{-}, \mathrm{CH}_{2} \mathrm{OHSO}_{2}^{-} \text {, } \\
\mathrm{CH}_{2} \mathrm{OHSO}_{3}^{-}\end{array}$ \\
\hline $\mathrm{Cl}^{-}, \mathrm{Cl}_{2}^{-}, \mathrm{ClO}^{-}, \mathrm{ClOH}^{-}$ \\
\hline $\mathrm{Br}^{-}, \mathrm{Br}_{2}^{-}, \mathrm{BrO}^{-}, \mathrm{BrCl}_{2}^{-}, \mathrm{Br}_{2} \mathrm{Cl}^{-}, \mathrm{BrOH}^{-}$ \\
\hline $\mathrm{I}^{-}, \mathrm{IO}_{2}^{-}, \mathrm{IO}_{3}^{-}, \mathrm{ICl}_{2}^{-}, \mathrm{IBr}_{2}^{-}, \mathrm{IClBr}^{-}$ \\
\hline
\end{tabular}









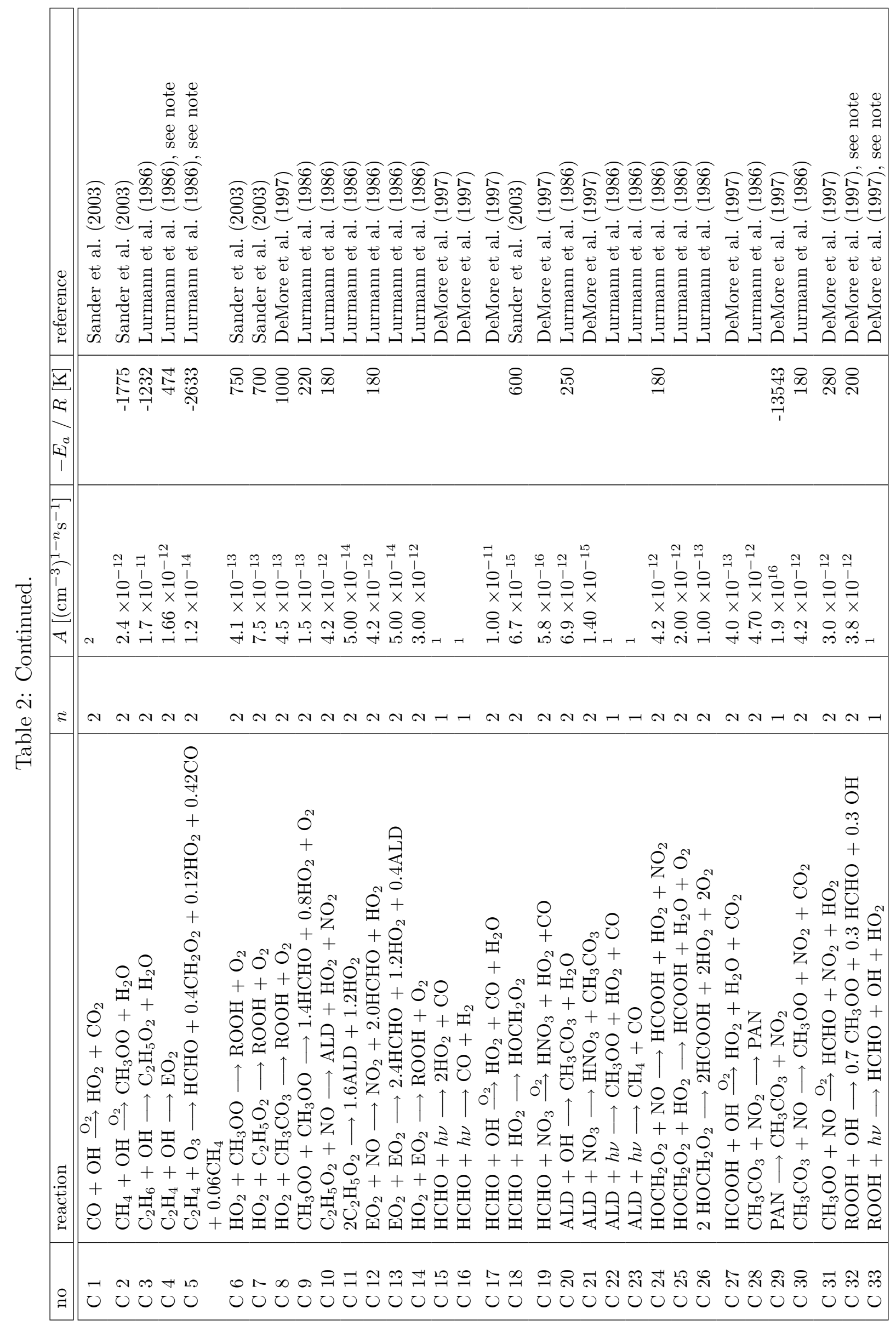




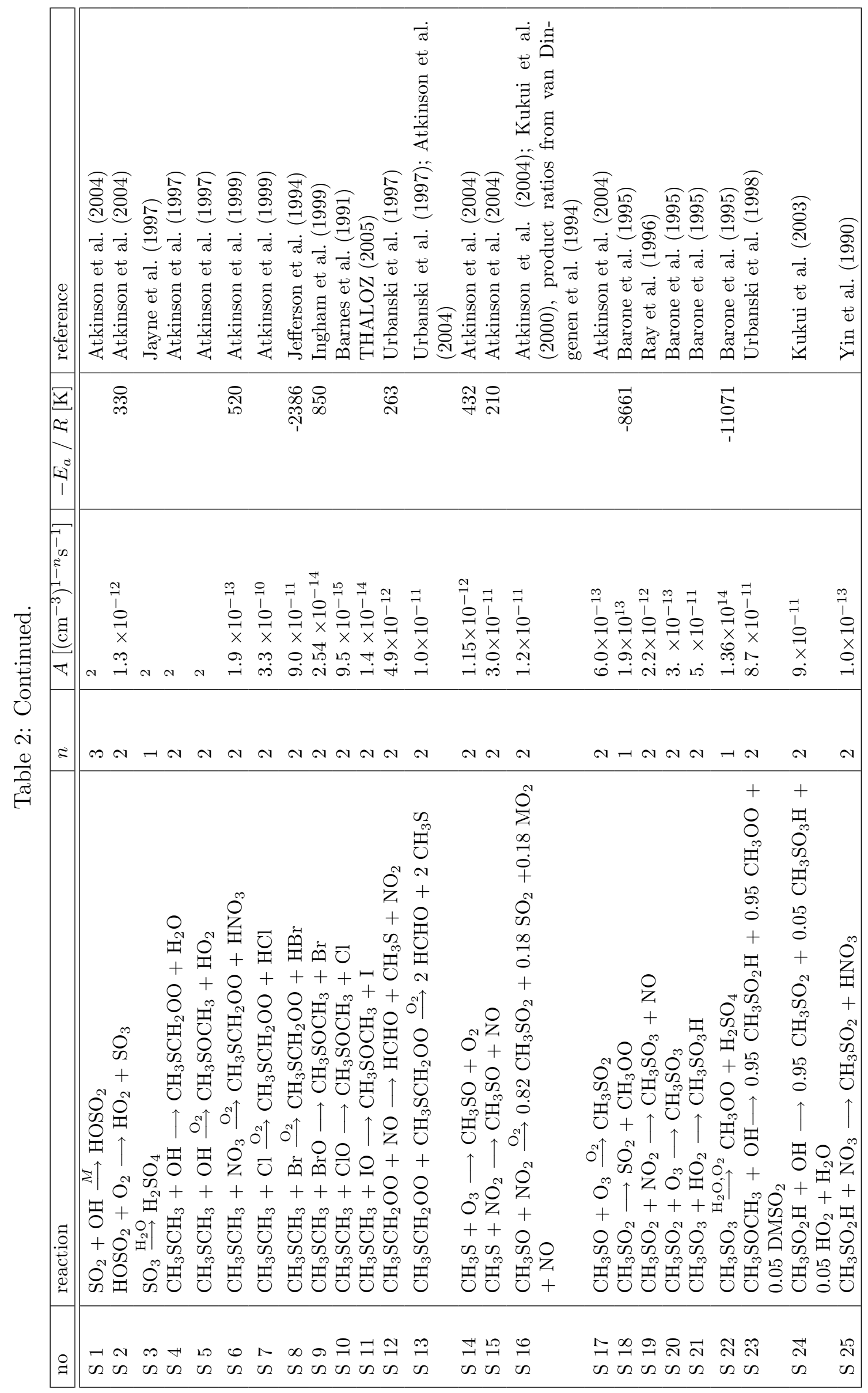




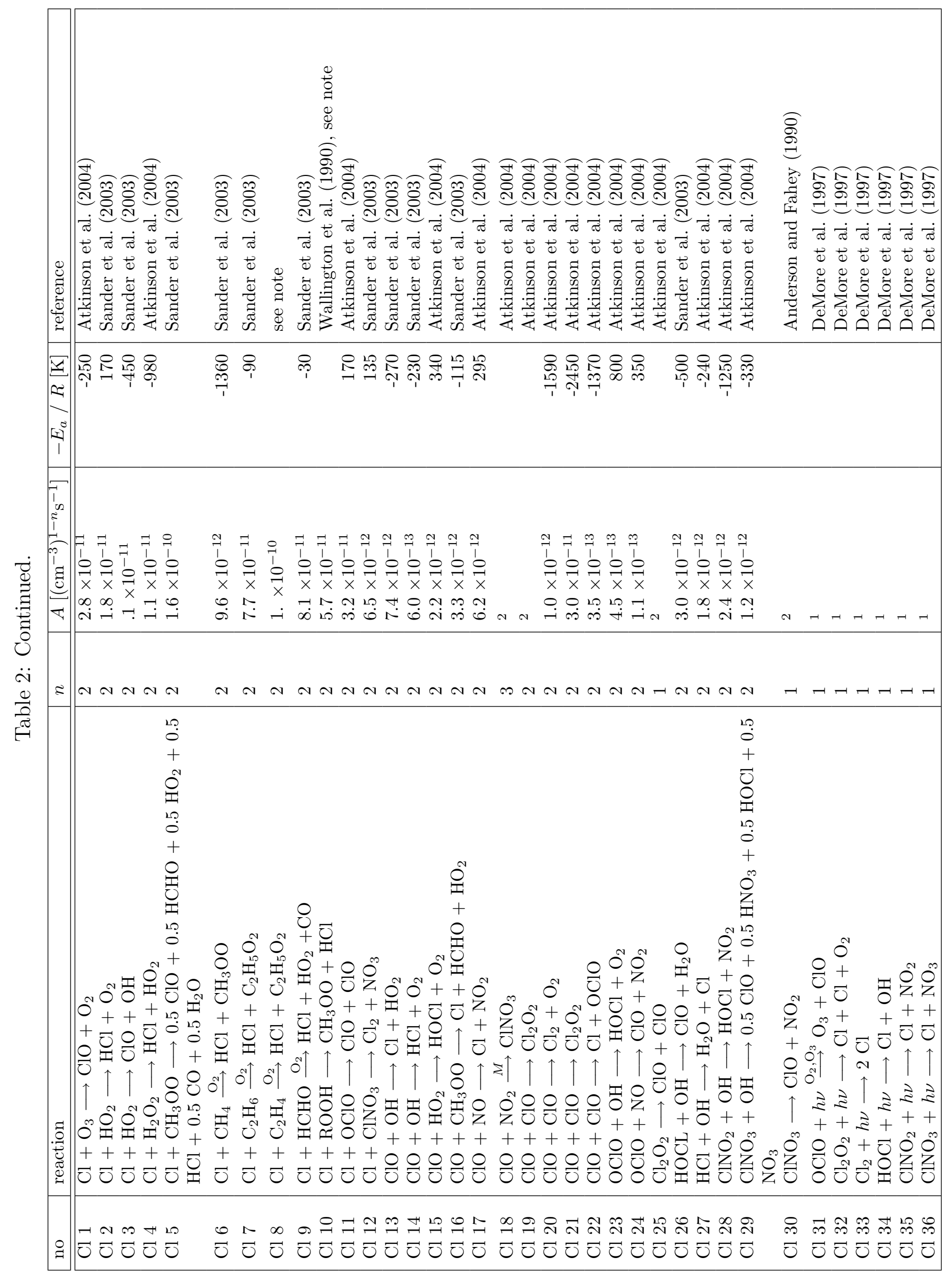




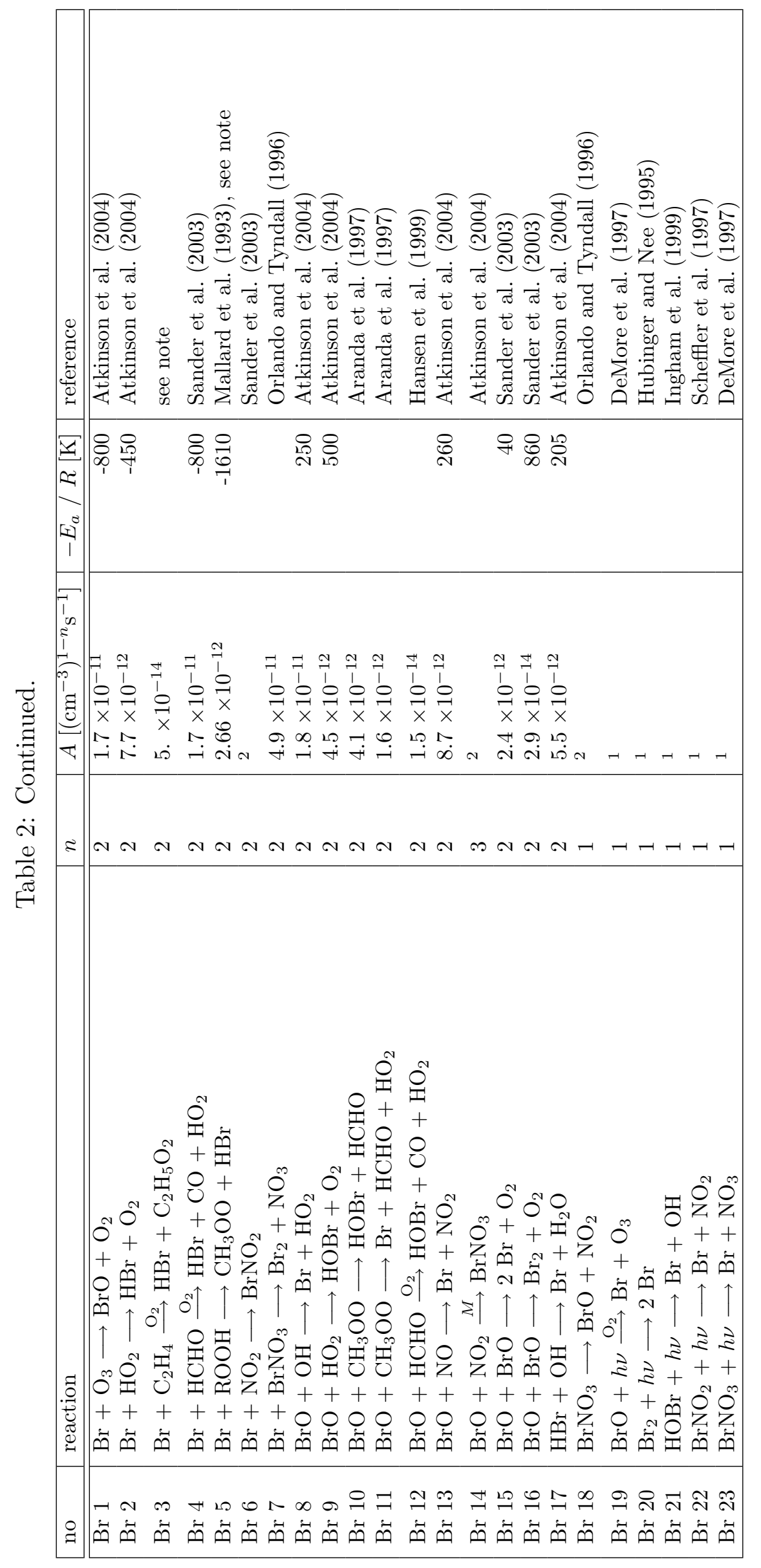









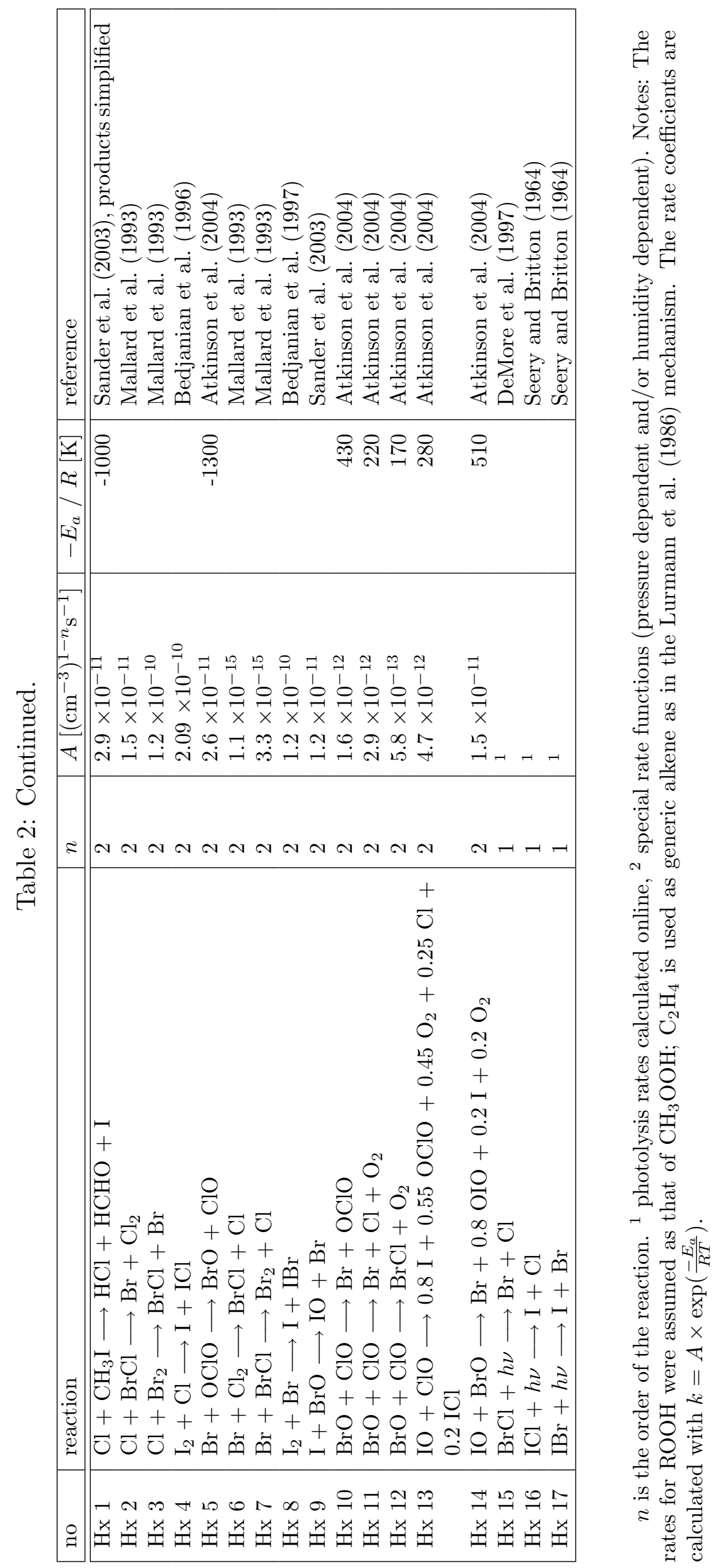




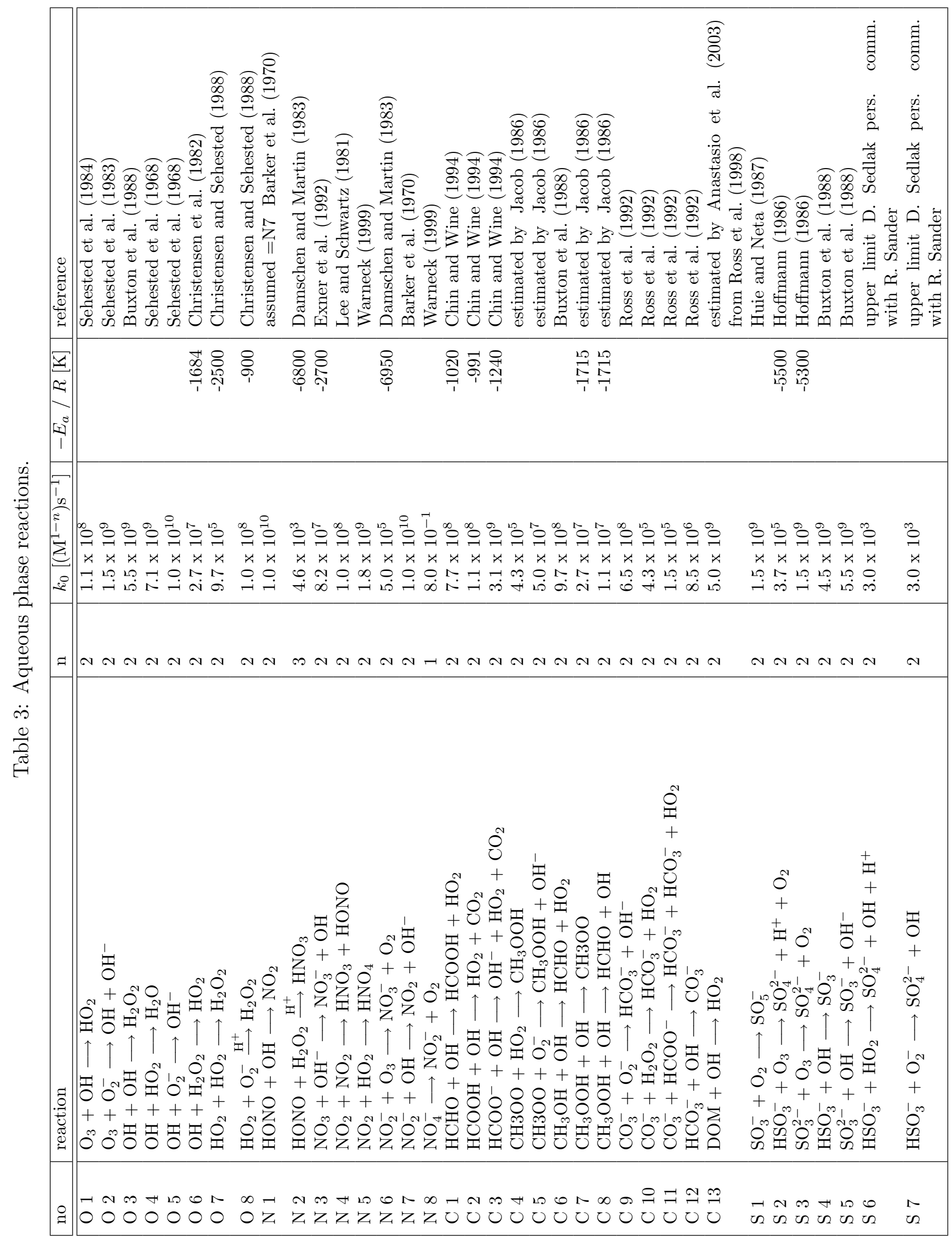









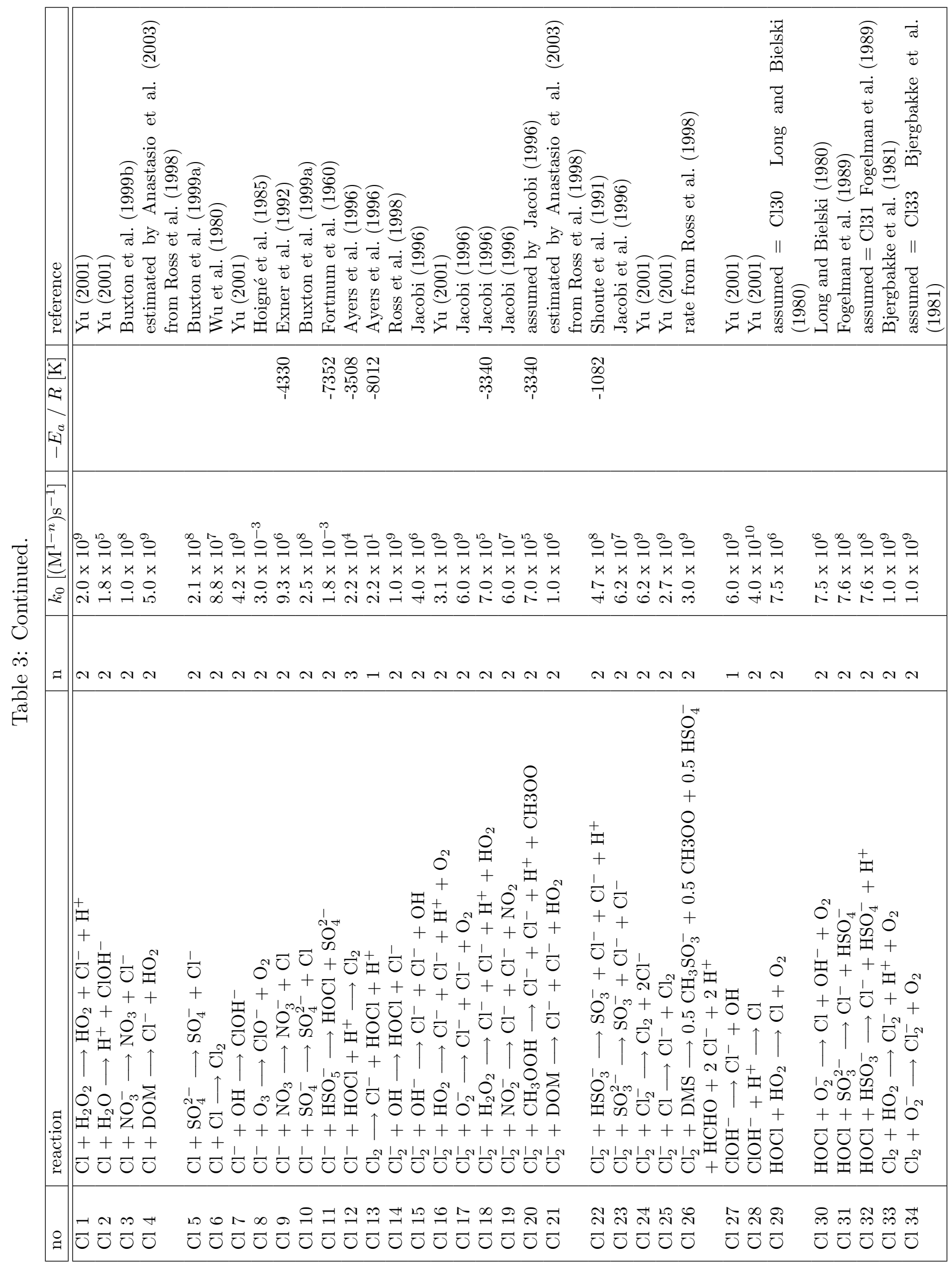




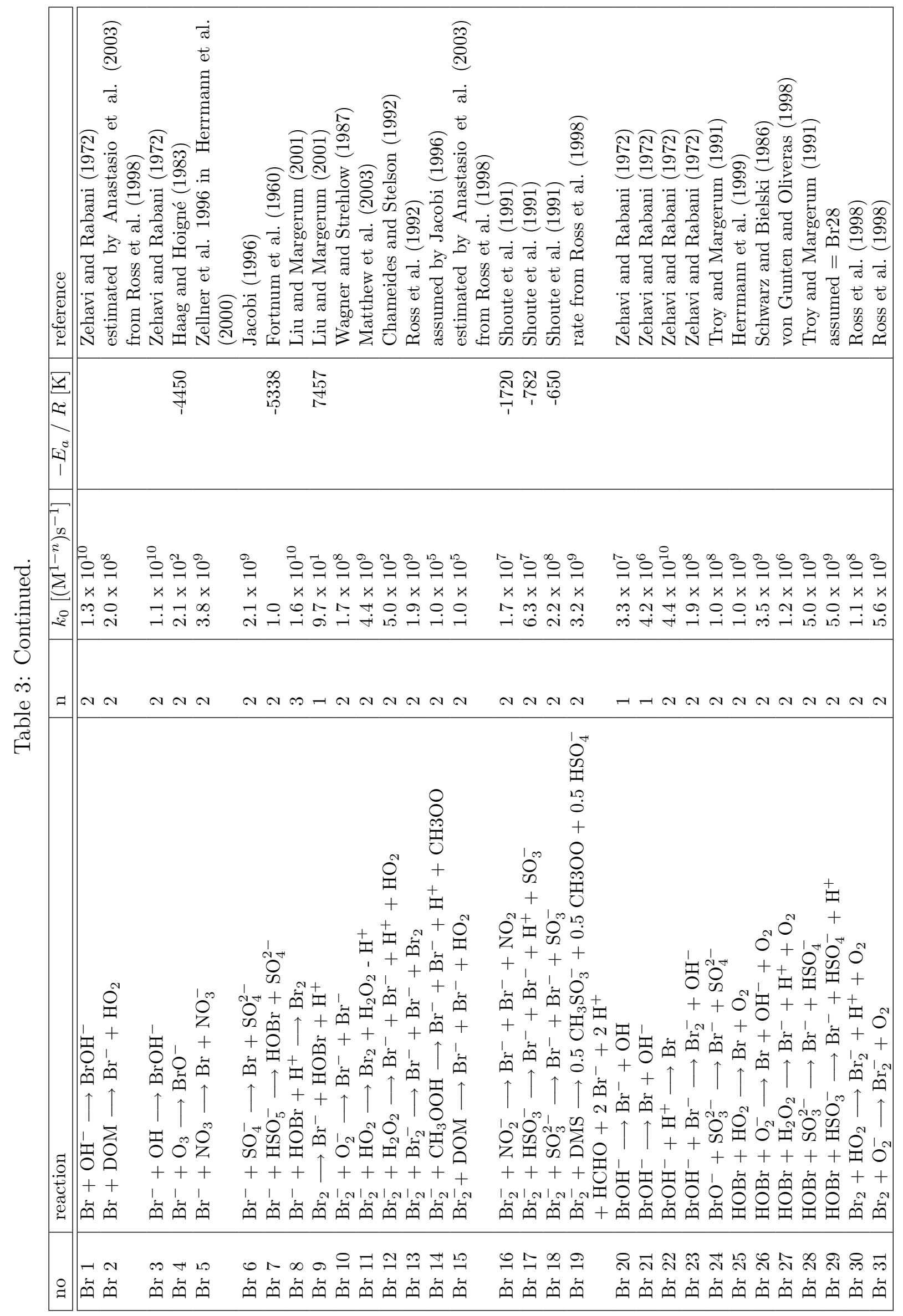









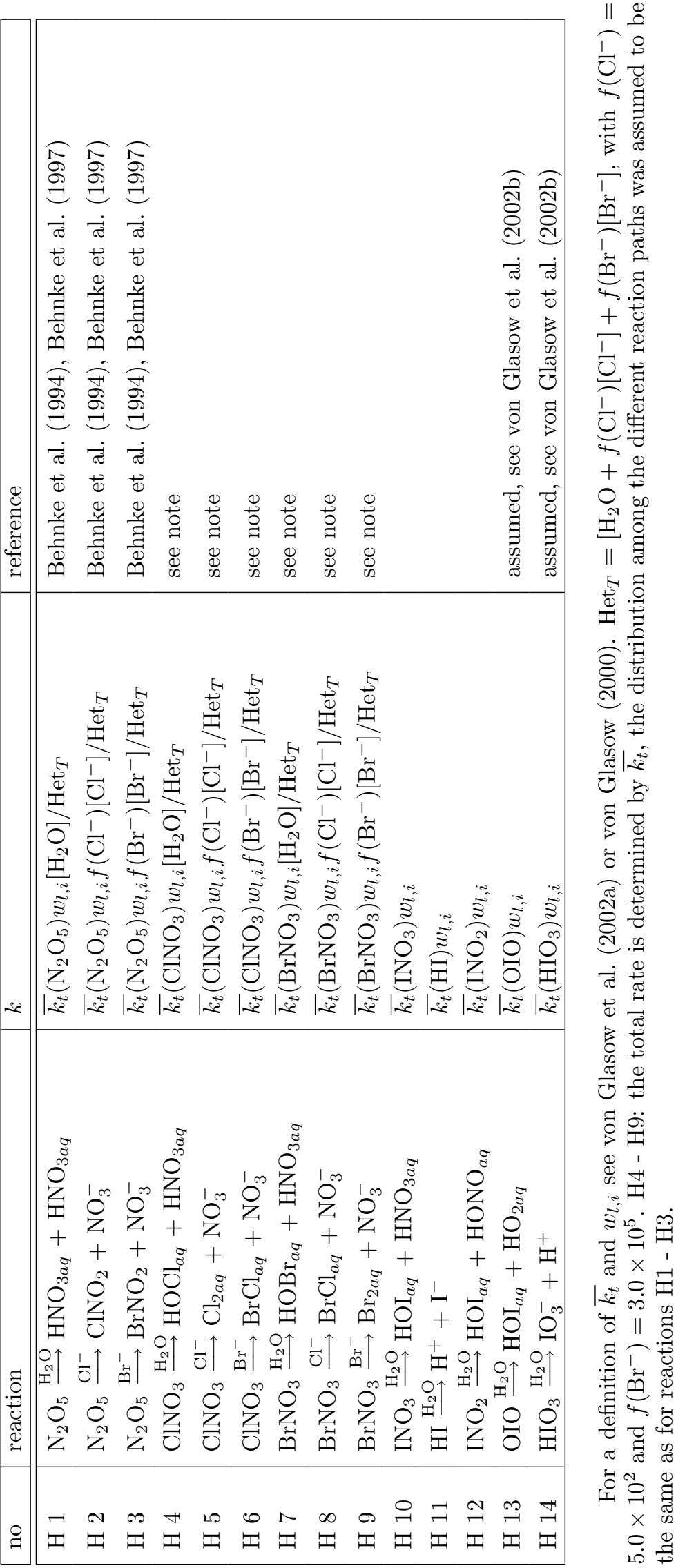




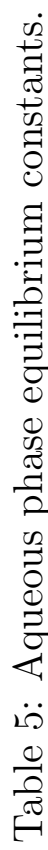

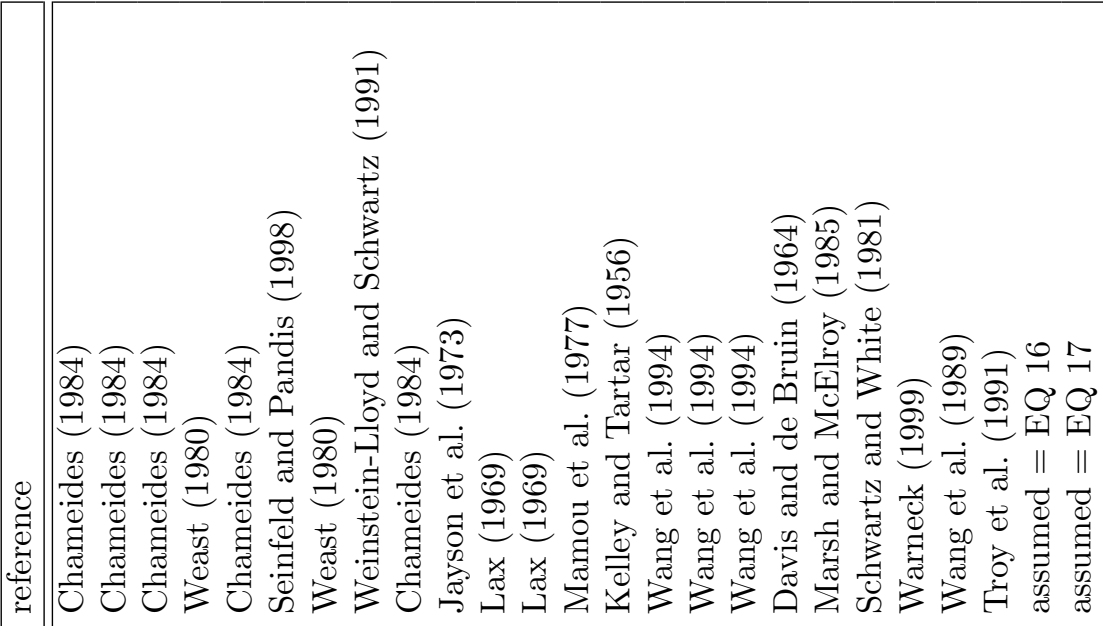

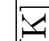


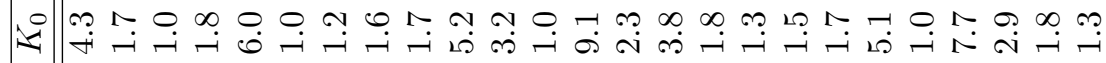

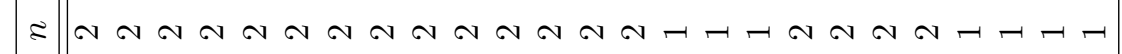

( $)$

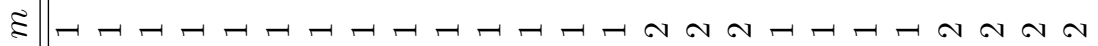



俩

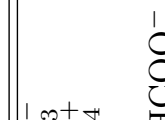

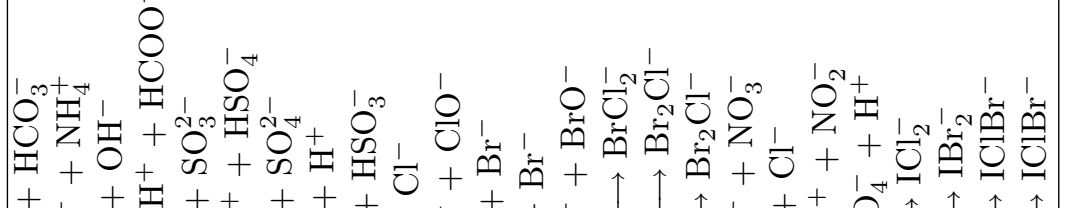



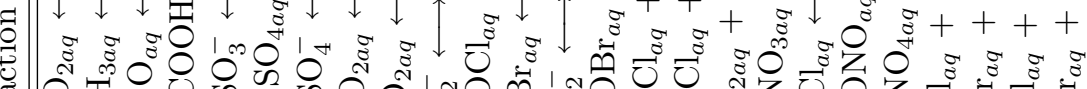

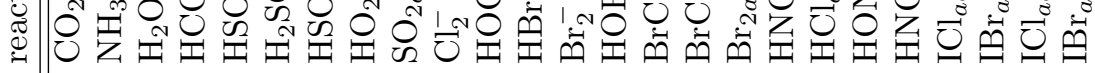

수

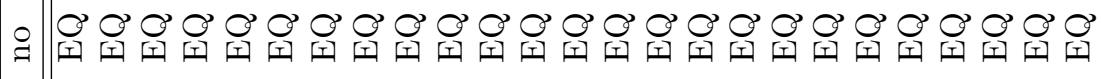




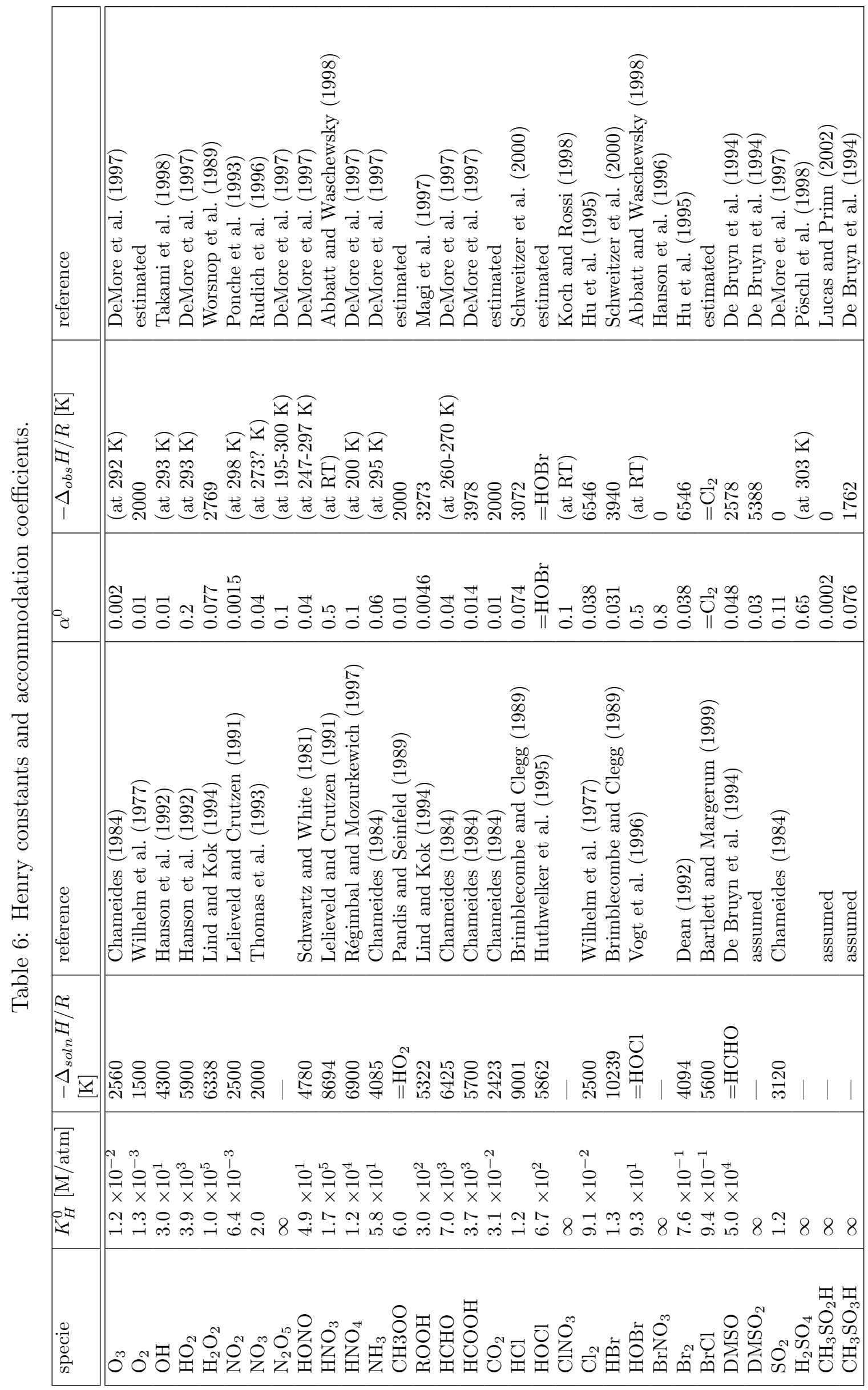









\section{References}

Abbatt, J. P. D. and Waschewsky, G. C. G.: Heterogeneous interactions of $\mathrm{HOBr}, \mathrm{HNO}_{3}, \mathrm{O}_{3}$ and $\mathrm{NO}_{2}$ with deliquescent $\mathrm{NaCl}$ aerosols at room temperature, J. Phys. Chem. A, 102, 3719 - 3725, 1998.

Anastasio, C., Matthew, B. M., Newberg, J. T., and George, I.: Photochemical formation of hydroxyl radical in sea=salt particles leads to the release of $\mathrm{Br}_{2}$, submitted, 2003.

Anderson, L. C. and Fahey, D. W.: Studies with $\mathrm{ClONO}_{2}$ : Thermal dissociation rate and catalytic conversion to $\mathrm{NO}$ using an $\mathrm{NO} / \mathrm{O}_{3}$ chemiluminescence detector, J. Phys. Chem., 94, 644 - 652, 1990.

Aranda, A., Le Bras, G., La Verdet, G., and Poulet, G.: The $\mathrm{BrO}+\mathrm{CH}_{3} \mathrm{O}_{2}$ reaction: Kinetics and role in the atmospheric ozone budget, Geophys. Res. Lett., 24, 2745 - 2748, 1997.

Atkinson, A., Baulch, D. L., Cox, R. A., Hampson, Jr., R. F., Kerr, J. A., Rossi, M. J., and Troe, J.: Evaluated kinetic and photochemical data for atmospheric chemistry: Supplement VI, J. Phys. Chem. Ref. Data, 26, 1329 - 1499, 1997.

Atkinson, R., Baulch, D. L., Cox, R. A., Hampson, Jr., R. F., Kerr, J. A., Rossi, M. J., and Troe, J.: Summary of Evaluated Kinetic and Photochemical Data for Atmospheric Chemistry, Web Version, http://www.iupac-kinetic.ch.cam.ac.uk, 1999.

Atkinson, R., Baulch, D. L., Cox, R. A., Crowley, J. N., Hampson, R. F., Jenkin, R. G. H. M. E., Kerr, J. A., Rossi, M. J., and Troe, J.: Summary of Evaluated Kinetic and Photochemical Data for Atmospheric Chemistry, Web Version, Jul. 2004, http://www.iupac-kinetic.ch.cam.ac.uk, 2004.

Atkinson, R., Baulch, D. L., Cox, R. A., Crowley, J. N., Hampson, R. F., Hynes, R. G., Jenkin, M. E., Kerr, J. A., Rossi, M. J., and Troe, J.: Summary of Evaluated Kinetic and Photochemical Data for Atmospheric Chemistry, Web Version, Mar. 2005, http://www.iupac-kinetic.ch.cam.ac.uk, 2005.

Ayers, G. P., Penkett, S. A., Gillett, R. W., Bandy, B., Galbally, I. E., Meyer, C. P., Elsworth, C. M., Bentle, S. T., and Forgan, B. W.: The Annual Cycle of Peroxides and Ozone in Marine Air at Cape Grim, Tasmania, J. Atmos. Chem., 23, 221 - 252, 1996.

Bardouki, H., da Rosa, M. B., Mihalopoulos, N., Palm, W.-U., and Zetzsch, C.: Kinetics and mechanism of the oxidation of dimethylsulfoxide (DMSO) and methanesulfinate ( $\mathrm{MSI}^{-}$) in aqueous medium, Atmos. Environ., 36, 4627 - 4634, 2002.

Barker, G. C., Fowles, P., and Stringer, B.: Pulse radiolytic induced transient electrical conductance in liquid solutions, Trans. Faraday Soc., 66, 1509-1519, 1970.

Barnes, I., Bastian, V., Becker, K. H., and Overath, R. D.: Kinetic studies of the reactions of IO, BrO and ClO with DMS, Int. J. Chem. Kinet., 23, 579 - 591, 1991.

Barone, S. B., Turnipseed, A. A., and Ravishankara, A. R.: Role of adducts in the atmospheric oxidation of dimethyl sulfide, Faraday Discuss., 100, 39 - 54, 1995.

Bartlett, W. P. and Margerum, D. W.: Temperature dependencies of the Henry's law constant and the aqueous phase dissociation constant of bromine chloride, Environ. Sci. Technol., 33, 3410-3414, 1999.

Bauer, D., Ingham, T., Carl, S. A., Moortgat, G. K., and Crowley, J. N.: Ultraviolet-visible absorption cross sections of gaseous HOI and its photolysis at 355 nm, J. Phys. Chem. A, 102, 2857-2864, 1998. 
Bedjanian, Y., Bras, G. L., and Poulet, G.: Rate constants for the reactions of I + OClO, I $+\mathrm{ClO}, \mathrm{Cl}$ $+\mathrm{I}_{2}$, and $\mathrm{Cl}+\mathrm{IO}$ and heat formation of IO radicals, J. Phys. Chem., 100, $15130-15136,1996$.

Bedjanian, Y., Bras, G. L., and Poulet, G.: Kinetic study of the $\mathrm{Br}+\mathrm{IO}, \mathrm{I}+\mathrm{BrO}$ and $\mathrm{Br}+\mathrm{I}_{2}$ reactions. Heat formation of the BrO radical, Chem. Phys. Lett., 266, 233 - 238, 1997.

Behnke, W., Scheer, V., and Zetzsch, C.: Production of $\mathrm{BrNO}_{2}, \mathrm{Br}_{2}$ and $\mathrm{ClNO}_{2}$ from the Reaction between Sea Spray Aerosol and $\mathrm{N}_{2} \mathrm{O}_{5}$, J. Aerosol Sci., 25, Suppl.1, S277 - S278, 1994.

Behnke, W., George, C., Scheer, V., and Zetzsch, C.: Production and decay of $\mathrm{ClNO}_{2}$ from the reaction of gaseous $\mathrm{N}_{2} \mathrm{O}_{5}$ with $\mathrm{NaCl}$ solution: Bulk and aerosol experiments, J. Geophys. Res., 102, 3795 3804, 1997.

Betterton, E. A. and Hoffmann, M. R.: Oxidation of aqueous $\mathrm{SO}_{2}$ by peroxymonosulfate, J. Phys. Chem., 92, 5962-5965, 1988.

Bjergbakke, E., Navartnam, S., Parsons, B. J., and Swallow, A. J.: Reaction between $\mathrm{HO}_{2}$. and chlorine in aqueous solution, J. Am. Chem. Soc., 103, 5926-5928, 1981.

Bonsang, B., Martin, D., Lambert, G., Kanakidou, M., de Roulley, J., and Sennequir, G.: Vertical distribution of nonmethane hydrocarbons in the remote marine boundary layer, J. Geophys. Res., 96, $7313-7324,1991$.

Boyce, S. D. and Hoffmann, M. R.: Kinetics and mechanism of the formation of hydroxymethanesulfonic acid at low pH, J. Phys. Chem., 88, 4740-4746, 1984.

Brimblecombe, P. and Clegg, S. L.: Erratum, J. Atmos. Chem., 8, 95, 1989.

Bröske, R. and Zabel, F.: Spectroscopic and kinetic properties of $\mathrm{XNO}_{2}(\mathrm{X}=\mathrm{Br}, \mathrm{I})$, Ann. Geophys. Suppl. II, 16, C717, 1998.

Burley, J. D. and Johnston, H. S.: Ionic mechanisms for heterogeneous stratospheric reactions and ultraviolet photoabsorption cross-sections for $\mathrm{NO}_{2}^{+}, \mathrm{HNO}_{3}$, and $\mathrm{NO}_{3}^{-}$in sulfuric-acid, Geophys. Res. Lett., 19, 1359 - 1362, 1992.

Buxton, G. V., Kilner, C., and Sellers, R. M.: Pulse radiolysis of HOI and $\mathrm{IO}^{-}$in aqeuous solution, formation and characterization of $\mathrm{I}^{\mathrm{II}}$, in 6th. Symp. on Radiation Chemistry, pp. 155 - 159, 1986.

Buxton, G. V., Greenstock, C. L., Helman, W. P., and Ross, A. B.: Critical review of rate constants for reactions of hydrated electrons, hydrogen atoms and hydroxyl radicals $\left(\cdot \mathrm{OH} / \cdot \mathrm{O}^{-}\right)$in aqueous solution, J. Phys. Chem. Ref. Data, 17, 513-886, 1988.

Buxton, G. V., McGowan, S., Salmon, G. S., Williams, J. E., and Wood, N. D.: A study of the spectra and reactivity of oxysulphur-radical anions involved in the chain oxidation of S(IV): A pulse and $\gamma$-radiolysis study, Atmos. Environ., 30, 2483-2493, 1996.

Buxton, G. V., Bydder, M., and Salmon, G. A.: The reactivity of chlorine atoms in aqueous solution Part II: The equilibrium $\mathrm{SO}_{4}^{-}+\mathrm{Cl}^{-} \longleftrightarrow \mathrm{Cl}+\mathrm{SO}_{4}^{2-}$, Phys. Chem. Chem. Phys., 1, $269-273,1999$ a.

Buxton, G. V., Salmon, G. A., and Wang, J.: The equilibrium $\mathrm{NO}_{3}+\mathrm{Cl}^{-} \longleftrightarrow \mathrm{NO}_{3}^{-}+\mathrm{Cl}$ : A laser flash photolysis and pulse radiolysis study of the reactivity of $\mathrm{NO}_{3}$ with chloride ion in aqueous solution, Phys. Chem. Chem. Phys., 1, 3589 - 3593, 1999b. 
Chambers, R. M., Heard, A. C., and Wayne, R. P.: Inorganic gas-phase reactions of the nitrate radical: $\mathrm{I}_{2}+\mathrm{NO}_{3}$ and $\mathrm{I}+\mathrm{NO}_{3}$, J. Phys. Chem., 96, 3321-3331, 1992.

Chameides, W. L.: The Photochemistry of a Remote Marine Stratiform Cloud, J. Geophys. Res., 89, $4739-4755,1984$.

Chameides, W. L. and Stelson, A. W.: Aqueous-Phase Chemical Processes in Deliquescent Sea-Salt Aerosols: A Mechanism That Couples the Atmospheric Cycles of S and Sea Salt, J. Geophys. Res., 97, $20565-20580,1992$.

Chatfield, R. B. and Crutzen, P. J.: Are There Interactions of Iodine and Sulfur Species in Marine Air Photochemistry?, J. Geophys. Res., 95, 22319 - 22 341, 1990.

Chin, M. and Wine, P. H.: A temperature-dependent competitive kinetics study of the aqueous-phase reactions of $\mathrm{OH}$ radicals with formate, formic acid, acetate, acetic acid, and hydrated formaldehyde, in Aquatic and Surface Photochemistry, edited by G. R. Helz, R. G. Zepp, and D. G. Crosby, pp. 85-96, A. F. Lewis, NY, 1994.

Chinake, C. R. and Simoyi, R. H.: Kinetics and mechanism of the complex bromate-iodine reaction, J. Phys. Chem., 100, 1643-1656, 1996.

Christensen, H. and Sehested, K.: $\mathrm{HO}_{2}$ and $\mathrm{O}_{2}^{-}$radicals at elevated temperatures, J. Phys. Chem., 92, 3007-3011, 1988.

Christensen, H., Sehested, K., and Corfitzen, H.: Reactions of hydroxyl radicals with hydrogen peroxide at ambient and elevated temperatures, J. Phys. Chem., 86, 1588-1590, 1982.

Citri, O. and Epstein, I. R.: Mechanistic study of a coupled chemical oscillator: the bromate-chloriteiodide reaction, J. Phys. Chem., 92, 1865-1871, 1988.

Clifton, C. L., Altstein, N., and Huie, R. E.: Rate constant for the reaction of $\mathrm{NO}_{2}$ with sulfur(IV) over the $\mathrm{pH}$ range 5.3-13, Environ. Sci. Technol., 22, 586-589, 1988.

Damschen, D. E. and Martin, L. R.: Aqueous aerosol oxidation of nitrous acid by $\mathrm{O}_{2}, \mathrm{O}_{3}$ and $\mathrm{H}_{2} \mathrm{O}_{2}$, Atmos. Environ., 17, 2005-2011, 1983.

Davis, Jr., W. and de Bruin, H. J.: New activity coefficients of 0-100 per cent aqueous nitric acid, J. Inorg. Nucl. Chem., 26, 1069 - 1083, 1964.

De Bruyn, W. J., Shorter, J. A., Davidovits, P., Worsnop, D. R., Zahniser, M. S., and Kolb, C. E.: Uptake of gas phase sulfur species methanesulfonic acid, dimethylsulfoxide, and dimethyl sulfone by aqueous surface, J. Geophys. Res., 99, 16927 - 16 932, 1994.

Dean, J. A.: Lange's Handbook of Chemistry, McGraw-Hill, Inc., 1992.

Deister, U. and Warneck, P.: Photooxidation of $\mathrm{SO}_{3}^{2-}$ in aqueous solution, J. Phys. Chem., 94, 2191-2198, 1990.

DeMore, W. B., Sander, S. P., Golden, D. M., Hampson, R. F., Kurylo, M. J., Howard, C. J., Ravishankara, A. R., Kolb, C. E., and Molina, M. J.: Chemical Kinetics and Photochemical Data for Use in Stratospheric Modeling, Tech. Rep. JPL Publication 97-4, Jet Propulsion Laboratory, Pasadena, CA, 1997. 
Eigen, M. and Kustin, K.: The kinetics of halogen hydrolysis, J. Am. Chem. Soc., 84, 1355 - 1361, 1962.

Exner, M., Herrmann, H., and Zellner, R.: Laser-based studies of reactions of the nitrate radical in aqueous solution, Ber. Bunsenges. Phys. Chem., 96, 470 - 477, 1992.

Fogelman, K. D., Walker, D. M., and Margerum, D. W.: Non-metal redox kinetics: Hypochlorite and hypochlorous acid reactions with sulfite, Inorg. Chem., 28, 986 - 993, 1989.

Fortnum, D. H., Battaglia, C. J., Cohen, S. R., and Edwards, J. O.: The kinetics of the oxidation of halide ions by monosubstituted peroxides, J. Am. Chem. Soc., 82, 778-782, 1960.

Furrow, S.: Reactions of iodine intermediates in iodate-hydrogen peroxide oscillators, J. Phys. Chem., 91, 2129-2135, 1987.

Gershenzon, M., Davidovits, P., Jayne, J. T., Kolb, C. E., and Worsnop, D. R.: Simultaneous Uptake of DMS and Ozone on Water, J. Phys. Chem. A, 105, 7031 - 7036, 2001.

Haag, W. R. and Hoigné, J.: Ozonation of bromide-containing waters: Kinetics of formation of hypobromous acid and bromate, Environ. Sci. Technol., 17, 261 - 267, 1983.

Haggerstone, A.-L., Carpenter, L. J., Carslaw, N., and McFiggans, G.: Improved model predictions of $\mathrm{HO}_{2}$ with gas to particle mass transfer rates calculated using aerosol number size distributions, J. Geophys. Res., 110, D04 303, doi: 10.1029/2004JD005 282, 2005.

Hansen, J. C., Li, Y., Francisco, J. S., and Li, Z.: On the Mechanism of the $\mathrm{BrO}+\mathrm{CH}_{2} \mathrm{O}$ Reaction, J. Phys. Chem. A, 103, $8543-8546,1999$.

Hanson, D. R., Burkholder, J. B., Howard, C. J., and Ravishankara, A. R.: Measurement of OH and $\mathrm{HO}_{2}$ radical uptake coefficients on water and sulfuric acid surfaces, J. Phys. Chem., 96, 4979-4985, 1992.

Hanson, D. R., Ravishankara, A. R., and Lovejoy, E. R.: Reaction of $\mathrm{BrONO}_{2}$ with $\mathrm{H}_{2} \mathrm{O}$ on submicron sulfuric acid aerosol and the implications for the lower stratosphere, J. Geophys. Res., 101D, 9063-9069, 1996.

Herrmann, H., Reese, A., and Zellner, R.: Time resolved UV/VIS diode array absorption spectroscopy of $\mathrm{SO}_{\mathrm{x}}^{-}(\mathrm{x}=3,4,5)$ radical anions in aqueous solution, J. Mol. Struct., 348, 183-186, 1995.

Herrmann, H., Ervens, B., Nowacki, P., Wolke, R., and Zellner, R.: A chemical aqueous phase radical mechanism for tropospheric chemistry, Chemosphere, 38, 1223 - 1232, 1999.

Herrmann, H., Ervens, B., Jacobi, H.-W., Wolke, R., Nowacki, P., and Zellner, R.: CAPRAM2.3: A Chemical Aqueous Phase Radical Mechanism for Tropospheric Chemistry, J. Atmos. Chem., 36, 231 - 284, 2000.

Hippler, H., Luther, K., and Troe, J.: Untersuchung der Rekombination von Jodatomen in stark komprimierten Gasen un dFlssigkeiten, Ber. Bunsenges. Phys. Chem., 77, 1104 - 1114, 1973.

Hoffmann, M. R.: On the kinetics and mechanism of oxidation of aquated sulfur dioxide by ozone, Atmos. Environ., 20, 1145 - 1154, 1986. 
Hoigné, J., Bader, H., Haag, W. R., and Staehelin, J.: Rate constants of reactions of ozone with organic and inorganic compounds in water - III Inorganic compounds and radicals, Wat. Res., 19, 993-1004, 1985 .

Hu, J. H., Shi, Q., Davidovits, P., Worsnop, D. R., Zahniser, M. S., and Kolb, C. E.: Reactive uptake of $\mathrm{Cl}_{2}$ and $\mathrm{Br}_{2}$ by aqueous surfaces as a function of $\mathrm{Br}^{-}$and $\mathrm{I}^{-}$ion concentration: The effect of chemical reaction at the interface, J. Phys. Chem., 99, 8768 - 8776, 1995.

Hubinger, S. and Nee, J. B.: Absorption spectra of $\mathrm{Cl}_{2}, \mathrm{Br}_{2}$ and $\mathrm{BrCl}$ between 190 and $600 \mathrm{~nm}$, J. Photochem. Photobiol. A: Chem., 86, 1-7, 1995.

Huie, R. E. and Neta, P.: Rate constants for some oxidations of S(IV) by radicals in aqueous solutions, Atmos. Environ., 21, 1743-1747, 1987.

Huthwelker, T., Clegg, S. L., Peter, T., Carslaw, K., Luo, B. P., and Brimblecombe, P.: Solubility of $\mathrm{HOCl}$ in water and aqueous $\mathrm{H}_{2} \mathrm{SO}_{4}$ to stratospheric temperatures, J. Atmos. Chem., 21, 81-95, 1995.

Ingham, T., Bauer, D., Sander, R., Crutzen, P. J., and Crowley, J. N.: Kinetics and Products of the Reactions BrO + DMS and Br + DMS at 298 K, J. Phys. Chem. A, 103, $7199-7209,1999$.

Jacob, D. J.: Chemistry of $\mathrm{OH}$ in Remote Clouds and Its Role in the Production of Formic Acid and Peroxymonosulfate, J. Geophys. Res., 91, 9807 - 9826, 1986.

Jacobi, H.-W.: Kinetische Untersuchungen und Modellrechnungen zur troposphärischen Chemie von Radikalanionen und Ozon in wässriger Phase, Ph.D. thesis, Universität Essen, Germany, 1996.

Jacobi, H.-W., Herrmann, H., and Zellner, R.: Kinetic investigation of the $\mathrm{Cl}_{2}^{-}$radical in the aqueous phase, in Air Pollution Research Report 57: Homogenous and hetrogenous chemical Processes in the Troposphere, edited by P. Mirabel, pp. 172-176, Office for official Publications of the European Communities, Luxembourg, 1996.

Jayne, J. T., Pöschl, U., Chen, Y., Dai, D., Molina, L. T., Worsnop, D. R., Kolb, C. E., and Molina, M. J.: Pressure and Temperature Dependence of the Gas-Phase Reaction of $\mathrm{SO}_{3}$ with $\mathrm{H}_{2} \mathrm{O}$ and the Heterogeneous Reaction of $\mathrm{SO}_{3}$ with $\mathrm{H}_{2} \mathrm{O} / \mathrm{H}_{2} \mathrm{SO}_{4}$ Surfaces, J. Phys. Chem. A, 101, $10000-10011$, 1997.

Jayson, G. G., Parsons, B. J., and Swallow, A. J.: Some simple, highly reactive, inorganic chlorine derivatives in aqueous solution, J. Chem. Soc. Faraday Trans., 69, 1597-1607, 1973.

Jefferson, A., Nicovich, J. M., and Wine, P. H.: Temperature-dependent kinetics studies of the reactions $\mathrm{Br}\left({ }^{2} \mathrm{P}_{3 / 2}\right)+\mathrm{CH}_{3} \mathrm{SCH}_{3} \leftrightarrow \mathrm{CH}_{3} \mathrm{SCH}_{2}+\mathrm{HBr}$. Heat of formation of the $\mathrm{CH}_{3} \mathrm{SCH}_{2}$ radical, J. Phys. Chem., 98, 7128 - 7135, 1994.

Jenkin, M. E., Cox, R. A., and Candeland, D. E.: Photochemical Aspects of Tropospheric Iodine behaviour, J. Atmos. Chem., 2, 359 - 375, 1985.

Jiang, P.-Y., Katsumura, Y., Nagaishi, R., Domae, M., Ishikawa, K., Ishigure, K., and Yoshida, Y.: Pulse radiolysis study of concentrated sulfuric acid solutions. Formation mechanism, yield and reactivity of sulfate radicals, J. Chem. Soc. Faraday Trans., 88, 1653-1658, 1992.

Kelley, C. M. and Tartar, H. V.: On the system: bromine-water, J. Am. Chem. Soc., 78, 5752-5756, 1956. 
Koch, T. G. and Rossi, M. J.: Direct measurement of surface residence times: Nitryl chloride and chlorine nitrate on alkali halides at room temperature, J. Phys. Chem. A, 102, 9193-9201, 1998.

Kukui, A., Bossoutrot, V., Laverdet, G., and Bras, G. L.: Mechanism of the Reaction of $\mathrm{CH}_{3} \mathrm{SO}$ with $\mathrm{NO}_{2}$ in Relation to Atmospheric Oxidation of Dimethyl Sulfide: Experimental and Theoretical Study, J. Phys. Chem. A, 104, 935 - 946, 2000.

Kukui, A., Borissenko, D., Laverdet, G., and Bras, G. L.: Gas phase reactions of OH radicals with dimethyl sulfoxide and methane sulfonic acid using turbulent flow reactor and chemical ionization mass spectrometry, J. Phys. Chem. A, 107, 5732 - 5742, 2003.

Kumar, K. and Margerum, D. W.: Kinetics and mechanism of general-acid-assisted oxidation of bromide by hypochlorite and hypochlorous acid, Inorg. Chem., 26, 2706 - 2711, 1987.

Laszlo, B., Kurylo, M. J., and Huie, R. E.: Absorption cross sections, kinetics of formation, and selfreaction of the $\mathrm{IO}$ radical produced via the laser photolysis of $\mathrm{N}_{2} \mathrm{O} / \mathrm{I}_{2} / \mathrm{N}_{2}$ mixtures, J. Phys. Chem., 99, $11701-11707,1995$.

Lax, E.: Taschenbuch für Chemiker und Physiker, Springer Verlag, Berlin, 1969.

Lee, Y.-N. and Schwartz, S. E.: Reaction kinetics of nitrogen dioxide with liquid water at low partial pressure, J. Phys. Chem., 85, 840-848, 1981.

Lelieveld, J. and Crutzen, P. J.: The Role of Clouds in Tropospheric Photochemistry, J. Atmos. Chem., 12, $229-267,1991$.

Lengyel, I., Li, J., Kustin, K., and Epstein, I. R.: Rate constants for reactions between iodine- and chlorine-containing species: A detailed mechanism of the chlorine dioxine/chlorite reaction, J. Am. Chem. Soc., 118, 3708-3719, 1996.

Lind, J. A. and Kok, G. L.: Correction to "Henry's law determinations for aqueous solutions of hydrogen peroxide, methylhydroperoxide, and peroxyacetic acid" by John A. Lind and Gregory L. Kok, J. Geophys. Res., 99D, 21 119, 1994.

Lind, J. A., Lazrus, A. L., and Kok, G. L.: Aqueous phase oxidation of sulfur(IV) by hydrogen peroxide, methylhydroperoxide, and peroxyacetic acid, J. Geophys. Res., 92D, 4171-4177, 1987.

Liu, Q. and Margerum, D. W.: Equilibrium and Kinetics of Bromine Chloride Hydrolysis, est, 35, 1127 $-1133,2001$.

Logager, T., Sehested, K., and Holcman, J.: Rate constants of the equilibrium reactions $\mathrm{SO}_{4}+\mathrm{HNO}_{3}$ $\longleftrightarrow \mathrm{HSO}_{4}^{-}+\mathrm{NO}_{3}$ and $\mathrm{SO}_{4}+\mathrm{NO}_{3} \longleftrightarrow \mathrm{SO}_{4}^{2-}+\mathrm{NO}_{3}$., Radiat. Phys. Chem., 41, $539-543,1993$.

Long, C. A. and Bielski, B. H. J.: Rate of reaction of superoxide radical with chloride-containing species, J. Phys. Chem., 84, 555-557, 1980.

Lucas, D. D. and Prinn, R. G.: Mechanistic studies of dimethylsulfide oxidation products using an observationally constrained model, J. Geophys. Res., 107, doi: 10.1029/2001JD000 843, 2002.

Lurmann, F. W., Lloyd, A. C., and Atkinson, R.: A Chemical Mechanism for Use in Long-Range Transport/Acid Deposition Computer Modeling, J. Geophys. Res., 91, 10905 - 10 936, 1986. 
Magi, L., Schweitzer, F., Pallares, C., Cherif, S., , Mirabel, P., and George, C.: Investigation of the uptake rate of ozone and methyl hydroperoxide by water surfaces, J. Phys. Chem. A, 101, 4943-4949, 1997.

Mallard, W. G., Westley, F., Herron, J. T., Hampson, R. F., and Frizzel, D. H.: NIST Chemical Kinetics Database: Version 5.0, National Institute of Standards and Technology, Gaithersburg, MD, 1993.

Mamou, A., Rabani, J., and Behar, D.: On the oxidation of aqueous $\mathrm{Br}^{-}$by $\mathrm{OH}$ radicals, studied by pulse radiolysis, J. Phys. Chem., 81, 1447-1448, 1977.

Marsh, A. R. W. and McElroy, W. J.: The dissociation constant and Henry's law constant of HCl in aqueous solution, Atmos. Environ., 19, 1075 - 1080, 1985.

Matthew, B. M., George, I., and Anastasio, C.: Hodroperoxyl radical $\left(\mathrm{HO}_{2}\right)$ oxidizes dibromide radical anion $\left(\mathrm{Br}_{2}^{-}\right)$to bromine $\left(\mathrm{Br}_{2}\right)$ in aqueous solution: Implication for the formation of $\mathrm{Br}_{2}$ in the marine boundary layer, to be submitted to GRL, 2003.

Mössinger, J., Shallcross, D. E., and Cox, R. A.: UV-VIS absorption cross-sections and atmospheric lifetimes if $\mathrm{CH}_{2} \mathrm{Br}_{2}, \mathrm{CH}_{2} \mathrm{I}_{2}$ and $\mathrm{CH}_{2} \mathrm{BrI}$, J. Chem. Soc. Faraday Trans., 94, $1391-1396,1998$.

Nagy, J. C., Kumar, K., and Margerum, D. W.: Non-metal redox kinetics: Oxidation of iodide by hypochlorous acid and by nitrogen trichloride measured by the pulsed-accelerated-flow method, Inorg. Chem., 27, 2773-2780, 1988.

Olsen, R. J. and Epstein, I. R.: Bifurcation analysis of chemical reaction mechanisms. I. Steady state bifurcation structure, J. Chem. Phys., 94, 3083-3095, 1991.

Orlando, J. J. and Tyndall, G. S.: Rate coefficients for the thermal decomposition of $\mathrm{BrONO}_{2}$ and the heat of formation of $\mathrm{BrONO}_{2}$, J. Phys. Chem., 100, 19398 - 19 405, 1996.

Palmer, D. A., Ramette, R. W., and Mesmer, R. E.: The hydrolysis of iodine: Equilibria at high temperatures, J. Nucl. Mater., 130, 280-286, 1985.

Pandis, S. N. and Seinfeld, J. H.: Sensitivity Analysis of a Chemical Mechanism for Aqueous-Phase Atmospheric Chemistry, J. Geophys. Res., 94, 1105 - 1126, 1989.

Ponche, J. L., George, C., and Mirabel, P.: Mass transfer at the air/water interface: Mass accommodation coefficients of $\mathrm{SO}_{2}, \mathrm{HNO}_{3}, \mathrm{NO}_{2}$ and $\mathrm{NH}_{3}$, J. Atmos. Chem., 16, 1-21, 1993.

Pöschl, U., Canagaratna, M., Jayne, J. T., Molina, L. T., Worsnop, D. R., Kolb, C. E., and Molina, M. J.: Mass accommodation coefficient of $\mathrm{H}_{2} \mathrm{SO}_{4}$ vapor on aqueous sulfuric acid surfaces and gaseous diffusion coefficient of $\mathrm{H}_{2} \mathrm{SO}_{4}$ in $\mathrm{N}_{2} / \mathrm{H}_{2} \mathrm{O}$, J. Phys. Chem. A, 102, $10082-10$ 089, 1998.

Ray, A., Vassalli, I., G.Laverdet, and Bras, G. L.: Kinetics of the Thermal Decomposition of the $\mathrm{CH}_{3} \mathrm{SO}_{2}$ Radical and Its Reaction with $\mathrm{NO}_{2}$ at 1 Torr and 298 K, J. Phys. Chem., 100, 8895 - 8900, 1996.

Régimbal, J.-M. and Mozurkewich, M.: Peroxynitric acid decay mechanisms and kinetics at low pH, J. Phys. Chem. A, 101, 8822-8829, 1997.

Roehl, C. M., Burkholder, J. B., Moortgat, G. K., Ravishankara, A. R., and Crutzen, P. J.: The temperature dependence of the UV absorption cross sections and the atmospheric implications of several alkyl iodides, J. Geophys. Res., 102D, 12 819-12 829, 1997. 
Ross, A. B., Mallard, W. G., Helman, W. P., Bielski, B. H. J., Buxton, G. V., Cabelli, D. E., Greenstock, C. L., Huie, R. E., and Neta, P.: NDRL-NIST Solution Kinetics Database: - Ver. 1, National Institute of Standards and Technology, Gaithersburg, MD, 1992.

Ross, A. B., Mallard, W. G., Helman, W. P., Buxton, G. V., Huie, R. E., and Neta, P.: NDRL-NIST Solution kinetics database: Version 3.0, Notre Dame Radiation Laboratory, Notre Dame, and National Institut of Standards and Technology, Gaithersburg, 1998.

Rudich, Y., Talukdar, R. K., Imamura, T., Fox, R. W., and Ravishankara, A. R.: Uptake of $\mathrm{NO}_{3}$ on KI solutions: Rate coefficient for the $\mathrm{NO}_{3}+\mathrm{I}^{-}$reaction and gas-phase diffusion coefficients for $\mathrm{NO}_{3}$, Chem. Phys. Lett., 261, 467-473, 1996.

Sander, S. P., Friedl, R. R., Golden, D. M., Kurylo, M. J., Huie, R. E., Orkin, V. L., Moortgat, G. K., Ravishankara, A. R., Kolb, C. E., Molina, M. J., and Finlayson-Pitts, B. J.: Chemical Kinetics and Photochemical Data for Use in Atmospheric Studies, Tech. Rep. JPL Publication 02-25, Jet Propulsion Laboratory, Pasadena, CA, 2003.

Scheffler, D., Grothe, H., Willner, H., Frenzel, A., and Zetzsch, C.: Properties of Pure Nitryl Bromide. Thermal Behaviour, UV/Vis and FTIR Spectra, and Photoisomerization to trans-BrONO in an Argon Matrix, Inorg. Chem., 36, 335 - 338, 1997.

Schwartz, S. E. and White, W. H.: Solubility equilibria of the nitrogen oxides and oxyacids in dilute aqueous solution, in Advances in Environmental Science and Engineering, edited by J. R. Pfafflin and E. N. Ziegler, vol. 4, pp. 1-45, Gordon and Breach Science Publishers, NY, 1981.

Schwarz, H. A. and Bielski, B. H. J.: Reactions of $\mathrm{HO}_{2}$ and $\mathrm{O}_{2}^{-}$with iodine and bromine and the $\mathrm{I}_{2}^{-}$and I atom reduction potentials, J. Phys. Chem., 90, 1445-1448, 1986.

Schweitzer, F., Mirabel, P., and George, C.: Uptake of hydrogen halides by water droplets, J. Phys. Chem. A, 104, 72-76, 2000.

Seery, D. J. and Britton, D.: The continous absorption spectra of chlorine, bromine, bromine chloride, iodine chloride, and iodine bromide, J. Phys. Chem., 68, 2263-2266, 1964.

Sehested, K., Rasmussen, O. L., and Fricke, H.: Rate constants of $\mathrm{OH}$ with $\mathrm{HO}_{2}, \mathrm{O}_{2}^{-}$, and $\mathrm{H}_{2} \mathrm{O}_{2}^{+}$from hydrogen peroxide formation in pulse-irradiated oxygenated water, J. Phys. Chem., 72, 626-631, 1968.

Sehested, K., Holcman, J., and Hart, E. J.: Rate constants and products of the reactions of $\mathrm{e}_{\mathrm{aq}}^{-}, \mathrm{O}_{2}^{-}$and H with ozone in aqueous solutions, J. Phys. Chem., 87, 1951-1954, 1983.

Sehested, K., Holcman, J., Bjergbakke, E., and Hart, E. J.: A pulse radiolytic study of the reaction $\mathrm{OH}$ $+\mathrm{O}_{3}$ in aqueous medium, J. Phys. Chem., 88, 4144-4147, 1984.

Seinfeld, J. H. and Pandis, S. N.: Atmospheric Chemistry and Physics, John Wiley \& Sons, New York, Chichester, Weinheim, 1998.

Shoute, L. C. T., Alfassi, Z. B., Neta, P., and Huie, R. E.: Temperature dependence of the rate constants for reaction of dihalide and azide radicals with inorganic reductants, J. Phys. Chem., 95, 3238 - 3242, 1991.

Takami, A., Kato, S., Shimono, A., and Koda, S.: Uptake coefficient of OH radical on aqueous surface, Chem. Phys., 231, 215-227, 1998. 
THALOZ: Final report of the EU project THALOZ: Tropospheric Halogens - effect on ozone, coordinated by R. A. Cox, University of Cambridge, U.K., 2005.

Thomas, K., Volz-Thomas, A., and Kley, D.: Zur Wechselwirkung von $\mathrm{NO}_{3}$-Radikalen mit wässrigen Lösungen: Bestimmung des Henry- und des Massenakkomodationskoeffizienten, Ph.D. thesis, Institut für Chemie und Dynamik der Geosphäre 2, Forschungszentrum Jülich GmbH, FRG, 1993.

Troy, R. C. and Margerum, D. W.: Non-metal redox kinetics: Hypobromite and hypobromous acid reactions with iodide and with sulfite and the hydrolysis of bromosulfate, Inorg. Chem., 30, $3538-$ 3543, 1991.

Troy, R. C., Kelley, M. D., Nagy, J. C., and Margerum, D. W.: Non-metal redox kinetics: Iodine monobromide reaction with iodide ion and the hydrolysis of IBr, Inorg. Chem., 30, 4838-4845, 1991.

Urbanski, S., Stickel, R. E., Zhao, Z. Z., and Wine, P. H.: Mechanistic and kinetic study of formaldehyde production in the atmospheric oxidation of dimethyl sulfide, J. Chem. Soc. Faraday Trans., 93, 2813 2819, 1997.

Urbanski, S., Stickel, R. E., and Wine, P. H.: Mechanistic and kinetic study of the gas-phase reaction of hydroxyl radical with dimethyl sulfoxide, J. Phys. Chem. A, 102, 10522 - 10 529, 1998.

van Dingenen, R., Jensen, N. R., Hjorth, J., and Raes, F.: Peroxynitrate Formation During the NightTime Oxidation of Dimethylsulfide: Its Role as a Reservoir Species for Aerosol Formation, J. Atmos. Chem., 18, $211-237,1994$.

Vogt, R., Crutzen, P. J., and Sander, R.: A mechanism for halogen release from sea-salt aerosol in the remote marine boundary layer, Nature, 383, 327 - 330, 1996.

Vogt, R., Sander, R., von Glasow, R., and Crutzen, P.: Iodine chemistry and its role in halogen activation and ozone loss in the marine boundary layer: A model study, J. Atmos. Chem., 32, 375 - 395, 1999.

von Glasow, R.: Modeling the gas and aqueous phase chemistry of the marine boundary layer, Ph.D. thesis, Universität Mainz, Germany, http://www.rolandvonglasow.de, 2000.

von Glasow, R., Sander, R., Bott, A., and Crutzen, P. J.: Modeling halogen chemistry in the marine boundary layer. 1. Cloud-free MBL, J. Geophys. Res., 107, 4341, doi: 10.1029/2001JD000 942, 2002a.

von Glasow, R., Sander, R., Bott, A., and Crutzen, P. J.: Modeling halogen chemistry in the marine boundary layer. 1. Cloud-free MBL, J. Geophys. Res., 107, 4341, doi: 10.1029/2001JD000 942, 2002b.

von Gunten, U. and Oliveras, Y.: Advanced oxidation of bromide-containing waters: Bromate formation mechanisms, Environ. Sci. Technol., 32, 63 - 70, 1998.

Wagman, D. D., Evans, W. H., Parker, V. B., Schummm, V. B., Halow, I., Bailey, S. M., Churney, K. L., and Nuttall, R. L.: The NBS tables of chemical thermodynamic properties; selected values for inorganic and C1 and C2 organic substances in SI units, J. Phys. Chem. Ref. Data, 11, Suppl. 2, 1982.

Wagner, I. and Strehlow, H.: On the flash photolysis of bromide ions in aqueous solution, Ber. Bunsenges. Phys. Chem., 91, 1317 - 1321, 1987.

Wallington, T. J., Andino, J. M., Ball, J. C., and Japar, S. M.: Fourier transform infrared studies of the reaction of $\mathrm{Cl}$ atoms with $\mathrm{PAN}, \mathrm{PPN}, \mathrm{CH}_{3} \mathrm{OOH}, \mathrm{HCOOH}, \mathrm{CH}_{3} \mathrm{COCH}_{3}$ and $\mathrm{CH}_{3} \mathrm{COC}_{2} \mathrm{H}_{5}$ at $295 \pm 2$ K, J. Atmos. Chem., 10, $301-313,1990$. 
Wang, T. X., Kelley, M. D., Cooper, J. N., Beckwith, R. C., and Margerum, D. W.: Equilibrium, kinetic, and UV-spectral characteristics of aqueous bromine chloride, bromine, and chlorine species, Inorg. Chem., 33, 5872 - 5878, 1994.

Wang, Y. L., Nagy, J. C., and Margerum, D. W.: Kinetics of hydrolysis of iodine monochloride measured by the pulsed-accelerated-flow method, J. Am. Chem. Soc., 111, 7838-7844, 1989.

Warneck, P.: The relative importance of various pathways for the oxidation of sulfur dioxide and nitrogen dioxide in sunlit continental fair weather clouds, Phys. Chem. Chem. Phys., 1, 5471 - 5483, 1999.

Wayne, R. P., Barnes, I., Biggs, P., Burrows, J. P., Canosa-Mas, C. E., Hjorth, J., Le Bras, G., Moortgat, G. K., Perner, D., Poulet, G., Restelli, G., and Sidebottom, H.: The nitrate radical: Physics, chemistry, and the atmosphere, Atmos. Environ., 25A, 1-203, 1991.

Weast, R. C., ed.: CRC Handbook of Chemistry and Physics, 61st Edition, CRC Press, Inc., Boca Raton, FL, 1980.

Weinstein-Lloyd, J. and Schwartz, S. E.: Low-intensity radiolysis study of free-radical reactions in cloudwater: $\mathrm{H}_{2} \mathrm{O}_{2}$ production and destruction, Environ. Sci. Technol., 25, 791-800, 1991.

Wesely, M. L.: Parameterization of surface resistances to gaseous deposition in regional-scale numerical models, Atmos. Environ., 23, 1293 - 1304, 1989.

Wilhelm, E., Battino, R., and Wilcock, R. J.: Low-pressure solubility of gases in liquid water, Chem. Rev., 77, 219-262, 1977.

Wine, P. H., Tang, Y., Thorn, R. P., Wells, J. R., and Davis, D. D.: Kinetics of aqueous phase reactions of the $\mathrm{SO}_{4}^{-}$radical with potential importance in cloud chemistry, J. Geophys. Res., 94D, 1085-1094, 1989 .

Worsnop, D. R., Zahniser, M. S., Kolb, C. E., Gardner, J. A., Watson, L. R., van Doren, J. M., Jayne, J. T., and Davidovits, P.: The temperature dependence of mass accommodation of $\mathrm{SO}_{2}$ and $\mathrm{H}_{2} \mathrm{O}_{2}$ on aqueous surfaces, J. Phys. Chem., 93, 1159-1172, 1989.

Wu, D., Wong, D., and Di Bartolo, B.: Evolution of $\mathrm{Cl}_{2}^{-}$in aqueous $\mathrm{NaCl}$ solutions, J. Photochem., 14, 303-310, 1980.

Yin, F., Grosjean, D., and Seinfeld, J. H.: Photooxidation of Dimethyl Sulfide and Dimethyl Disulfide. I: Mechanism Development, J. Atmos. Chem., 11, 309 - 364, 1990.

$\mathrm{Yu}, \mathrm{X} .-\mathrm{Y} .:$ Kinetics of free radical reactions generated by laser flash photolysis of $\mathrm{OH}+\mathrm{Cl}^{-}$and $\mathrm{SO}_{4}^{-}+\mathrm{Cl}_{-}$in the aqueous phase - Chemical mechanism, kinetics data and their implications, Ph.D. thesis, University of Michigan, Ann Arbor, 2001.

Zehavi, D. and Rabani, J.: Oxidation of aqueous bromide ions by hydroxyl radicals. Pulse radiolytic investigation, J. Phys. Chem., 76, 312 - 319, 1972.

Zellner, R., Exner, M., and Herrmann, H.: Absolute OH Quantum Yield in the Laser Photolysis of Nitrate, Nitrite and Dissolved $\mathrm{H}_{2} \mathrm{O}_{2}$ at 308 and $351 \mathrm{~nm}$ in the Temperature Range 278-353 K, J. Atmos. Chem., 10, 411 - 425, 1990. 